\title{
ANALISIS KRITIS IMPLEMENTASI TAKLID DALAM BERAGAMA DALAM TINJAUAN USHUL FIQH EMPAT MAZHAB DAN PENGARUHNYA TERHADAP NILAI-NILAI KEBANGSAAN NEGARA KESATUAN REPUBLIK INDONESIA (NKRI)
}

\author{
Alfa Syahriar \& Ahmad Fauzan Mubarok. \\ Universitas Islam Nahdlatul Ulama Jepara \\ alfasyahriar@unisnu.ac.id
}

\begin{abstract}
This study was conducted to discuss the concept of taklid in the religious activity in the perspective of Ushul Fiqh in four madhhab, with the consideration that at the level of implementation, the concept was still problematic, so the consequence was cause someone can easily fall into the trap of fanaticism that leads to radicalism, as a result of the weakening of critical reason-related the quality of the received religious information-and the barrenness of the creative power-related to the application of Islamic teachings in the reality of national and state life. Meanwhile, the values derived from the four pillars of nationality, namely Pancasila, the UUD 1945, NKRI and Bhineka Tunggal Ika, were the values agreed upon by all components of the nation as national identity, as well as the spirit of the nation's continuity, because these values were none other than the embodiment of the value of Islamic teachings, when faced with a concept of taklid that has the potential of fanaticism which lead to radicalism, it certainly opens the possibility of a threat to the integrity of NKRI. Therefore, with this consideration the study were done, to answer the problems, among others; the essence, validity and urgency of the concept of taklid in the perspective of Ushul Fiqh in the four madhhab, then the implementation of the concept of taklid and its influence on the national values of NKRI. This research uses library research and field research with qualitative-descriptive approach. The results of this study could be stated that taklid was a concept was taken by someone to bind themselves to the opinions of others in religious activities which according to Ushul Fiqh can be found justification argument, in according about its strategic position as a solution for the human kind. The concept of taklid had a significant influence on the existence of the nationality value of NKRI and would certainly be a threat when done without adequate space of reasoning.
\end{abstract}

Keywords: Taklid, Ushul Fiqh, Four Madhhab, NKRI.

\section{A. Pendahuluan}

Islam diturunkan dengan syariat yang mapan dan lengkap. Mapan dikandung maksud tidak ada lagi penambahan dan bersifat 
final. Lengkap dapat dipahami sudah mencakup seluruh aspek hidup dan kehidupan manusia. Syariat Islam hadir sebagai sebuah rangkaian aturan dan ajaran yang dengannya Allah Swt berkehendak untuk memastikan bahwa kehidupan ini berlangsung dalam suasana yang penuh cinta kasih, karena dengan kehidupan yang dilingkupi cinta kasih akan memudahkan tumbuh suburnya nilai-nilai kebaikan yang bermanfaat dalam kehidupan ini, yang sering disebut dengan istilah maslahah.

Selanjutnya, maklum adanya bahwa al-Qur'an dan al-Sunnah sebagai sumber utama diberlakukanya syariat Islam adalah sesuatu yang sudah selesai dan final. Sementara itu, dinamika sosial manusia tidak pernah mengenal surut, bahkan acap kali tidak pernah sunyi dari problematika yang mengundang polemik berkepanjangan. Oleh karena itu, menjadi perlu kiranya ada sebuah upaya, bagaimana supaya benang merah antara sumber hukum Islam yang final, dengan dinamika sosial manusia yang selalu aktual, dapat terhubung dengan baik.

Ijtihad merupakan sebuah istilah yang jamak dikenal dalam ranah pemikiran hukum Islam, sebagai sebuah sistem yang bisa dipakai untuk menentukan jalan keluar bagi permasalahan umat dengan berlandaskan pada nilai-nilai yang terkandung dalam alQuran dan al-Sunnah. Kendati ijtihad menjadi sebuah keniscayaan yang harus dilalui, hal itu tidak serta merta dapat dilakukan dengan serampangan, tanpa adanya prasarat yang melingkupinya, yang dapat dikaji lebih mendalam dalam literatur pemikiran hukum Islam yang tersedia.

Oleh karena itu para ulama memberi batasan yang ketat terkait prasarat ijtihad sehingga tidak sembarangan orang bisa menggunakannya. Bagi orang yang memenuhi kualifikasi ijtihad, para ulama bersepakat akan kewajiban orang tersebut berijtihad, sedangkan bagi kalangan awam yang tidak memenuhi kualifikasi tersebut, diwajibkan untuk mengambil sikap taklid.

Kendati demikian, realitas dari sikap taklid masih menyisakan persoalan. Pasalnya, sebagai akibat dari taklid, paling tidak akan berimbas pada dua hal, pertama, melemahnya nalar kritis umat Islam, terlebih dalam persoalan informasi keagamaan. Kedua, memudarnya daya kreatifitas seseorang, terkait dengan strategi penerapan hukum Islam di Indonesia. Kedua hal tersebut, akan mendorong seseorang-terlebih ketika ada sugesti yang 
mempengaruhi-mempunyai kecenderungan untuk bersikap radikal dan fanatik.

Islam di Indonesia telah disepakati bersama, sebagai Islam yang telah mengejawantahkan nilai-nilai ajarannya melebur ke dalam nilai-nilai luhur bangsa Indonesia. Prinsip kebhinekaan, dan kesatuan disepakati bersama sebagai nilai yang wajib hukumnya dan menjadi harga mati untuk dipertahankan oleh segenap komponen bangsa Indonesia.

Terkait dengan sikap taklid seseorang dalam beragama dengan segenap konsekuensinya, tentunya berpotensi ancaman terhadap Negara Kesatuan Republik Indonesia (NKRI). Oleh karena itu, dengan pertimbangan tersebut perlu kiranya diadakan kajian tentang pengaruh taklid dalam beragama terhadap nilai-nilai kebangsaan dalam NKRI. Dan kajian ini diperuntukkan untuk menjawab dari permasalahan tentang, hakekat, konsep, urgensi taklid dalam perspektif Ushul Fiqh empat mazhab untuk kemudian dapat menunjukkan keterpengaruhan taklid terhadap NKRI untuk mencari pola ideal taklid bagi umat Islam Indonesia.

Kajian ini dilakukan dengan metode kualitatif deskriptif yang dimaksudkan bahwa kajian ini berusaha menguak makna terdalam dari bahan kajian berikut latar belakang yang melingkupinya. Sementara itu terkait dengan jenis penelitian maka dapat dibagi menjadi dua, yaitu library research dan field research.

\section{B. Tinjauan Pustaka}

Pembahasan kata taklid dapat ditinjau dari dua sudut pandang, yaitu: pertama, sudut pandang bahasa, kata taklid termasuk dalam kata serapan dari kata تقليد yang berasal dari bahasa arab. Dalam ilmu shorof (morfologi) kata tersebut berbentuk masdar (kata dasar), dan merupakan turunan dari kata kerja قِّلّ Secara bahasa, kata taklid dapat menunjukkan beberapa arti, antara lain: ihatah (إحاطة) mempunyai arti mencakup, meliputi, membungkus, sehingga bisa dikatakan bahwa orang yang taklid sama halnya mengikuti orang lain dengan sebuah rantai yang melingkar di leher; ghita' (غطاء) berarti tutup, sehingga orang yang taklid sama halnya menutupi pikiran dan penalarannya terhadap sesuatu hal yang diikuti.

Di samping itu ada beberapa arti kata lainnya, yaitu: ilzam (إلزام) yang berarti menetapkan, sehingga orang yang taklid menetapkan dirinya untuk mengikuti pendapat tertentu; tatabbu

Yudisia, Vol. 9, No. 1, Jan-Jun 2018 
(تتبع) yang berarti mengikuti, sehingga orang yang taklid sama halnya mengambil suatu pendapat untuk selalu diikuti di setiap hari; al-Sabq (السبق) yang berarti dahulu, sehingga orang yang taklid telah didahului oleh orang yang diikuti dalam hal berfikir tentang sesuatu hal; al-Muhakah wa al-Ittiba ' min ghair tafkir (المحاكاة و الإتباع من غير تفكير) yang berarti menceritakan dan mengikuti suatu hal tanpa memikirkannya, sehingga seseorang yang taklid seolah menceritakan hal-hal yang terkait dengan orang yang diikuti, kemudian mengikutinya tanpa menggunakan penalaran yang memadai.

Kedua, sudut pandang istilah dalam disiplin Ushul Fiqh, kata taklid mempunyai ragam pengertian yang dapat dijelaskan dalam dua kategori, yaitu:

1. Definisi taklid ditinjau dari prasarat kapabilitas personal orang yang diikuti sebagai hujjah hukum . Tinjauan ini dapat dirincikan lagi ke dalam dua bagian:

a. Definisi yang tidak memprasyaratkan adanya kapabilitas personal dari orang yang diikuti sebagai hujjah

Isfirayini (1992, vol VI: 270) mendefinisikan taklid sebagai bentuk penerimaan seseorang terhadap pendapat orang tertentu tidak berdasarkan pada argumentasi yang jelas. AlJuwaini (1996: 18), Abu Manshur al-Baghdadi (1992, vol VI: 270) menjelaskan taklid dengan definisi serupa. Al-Baqilani memaparkan bahwa taklid adalah mengikuti seseorang tanpa adanya alasan tertentu, dan tidak bersandar pada ilmu. Kemudian al-Syairazi (1995: 251) menjelaskan bahwa taklid adalah penerimaan pendapat orang lain dengan tanpa dalil. Definisi yang dikemukakan al-Syairazi serupa dengan yang dipaparkan oleh Abu Ya'la (1993, vol V:1601-1603), Ibnu Taimiyyah (tt: 462), Ibnu Juzzai (2002: 444), dan 'Akbari (2007: 157-158).

b. Definisi yang memprasyaratkan adanya kapabilitas personal dari orang yang diikuti sebagai hujjah

Al-Qaffal mendefinisikan bahwa taklid adalah penerimaan terhadap pendapat orang tertentu, dan tidak diketahui darimana pendapat tersebut ditetapkan (Al Zarkasyi, 1992, vol VI: 270). Al-Nasafi menyatakan bahwa taklid adalah mengikuti orang lain terhadap pendapat yang didengar darinya dengan tanpa mengetahui dasar dari pendapat tersebut. 
2. Definisi taklid ditinjau dari diksi yang dipakai:

a. Definisi taklid dengan memakai diksi qabul (قبول) Imam al-Haramain (1399: 1357) dan al-Ghazali (tt: 703), mendefinisikan taklid dengan menggunakan susunan redaksi sebagai berikut:

"penerimaan pendapat orang lain tanpa adanya alasan tertentu"

Al Syaukani (2000, vol II: 1081) mengutip pendapat AlQaffal dengan menyatakan definisi yang hampir sama, yaitu:

$$
\text { قبول قول الغير و أنت لا تدري من أين أنى بقوله. }
$$

"penerimaan pendapat orang lain, padahal tidak dapat diketahui asal muasal pendapat yang diketahui".

Al-Syaukani menuturkan definisi taklid sebagai berikut:

$$
\text { قبول رأي من لا تقوم به الحجة بلا حجة. }
$$

"penerimaan pendapat seseorang yang tidak dapat diketahui kredibilitasnya sebagai acuan hukum, dengan tanpa alasan". Al-Shan'ani menjelaskan definisi taklid dengan redaksi sebagai berikut:

$$
\text { قبول قول الغير بلا مطالبة بحجة. }
$$

"penerimaan pendapat orang lain dengan tanpa adanya penelusuran terhadap argumentasi yang menjadi acuan pendapat orang lain tersebut".

b. Definisi taklid dengan memakai diksi amal (عمل)

Muhib Allah ibn Abd al-Syakur (2002, vol II: 432) mendefinisikan taklid dengan redaksi sebagai berikut:

$$
\text { العمل بقول الغير من غير حجة. }
$$

"mengamalkan pendapat orang lain tanpa adanya alasan (yang dibenarkan)".

Dengan redaksi serupa, al-Amidi (2003, vol IV: 269) menambahkan satu kata ملزمة, sehingga redaksinya sebagai berikut:

$$
\text { العمل بقول الغير من غير حجة ملزمة. }
$$

"mengamalkan pendapat orang lain tanpa adanya alasan yang mengikat".

Ibn al-Hammam (1351: 547) memberi penjelasan yang berbeda:

$$
\text { العمل بقول من ليس قوله أحدى الحجج بلا حاجة منه. }
$$


"mengamalkan pendapat seseorang yang tidak mempunyai kapabilitas sebagai hujjah dengan tanpa alasan yang dibenarkan"

c. Definisi taklid dengan memakai diksi akhaza (أخذ)

Ibn al-Najjar (1993, vol IV: 529) menjelaskan taklid dengan redaksi sebagai berikut:

$$
\text { أخذ مذهب الغير بلا معرفة دليله }
$$

"mengambil pendapat mazhab lain dengan tanpa mengetahui dalilnya".

Sebagian Ulama mazhab Hanbali menyatakan sebagai berikut:

$$
\text { أخذ القول من غير قيام حجة على الأخذ. }
$$

"Mengambil pendapat tertentu tanpa adanya alasan dalam pengambilannya"

d. Definisi taklid dengan memakai diksi ittiba ' (إنباع)

'Ala' al-Din al-Samarqandi menerangkan sebagai berikut:

إنباع الرجل الجاهل العالم لعلمه وور عاه واعتقاده لما يعتقده على طريق الجزم

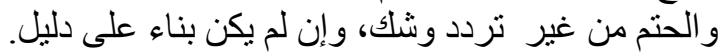

"ikutnya orang bodoh kepada orang alim karena keilmuannya, wara'nya, dan keyakinannya terhadap apa yang diyakini oleh orang alim tersebut dengan keyakinan dan kemantapan tanpa adanya keraguan, meskipun tanpa berdasarkan argumentasi tertentu".

e. Definisi taklid dengan memakai diksi iltizam (إلتزام)

Abdullah al-Syinqithi (tt, vol II: 335-336) memaparkan definisi taklid sebagai berikut:

$$
\text { إلتز ام مذهب الغير بلا علم لدليله الخاص. }
$$

"menetap pada mazhab orang lain dengan tanpa mengetahui dalilnya secara khusus".

Demikian pula, kata taklid dapat dilihat dari perspektif disiplin ilmu sosial, bahwa pada dasarnya setiap individu di dalam setiap komunitas tidak dimungkinkan terhindar dari taklid atau dikenal dengan sikap imitasi. Satu individu dipastikan akan mengikuti individu yang lain. Seorang anak adalah wajar jika mengikuti orang tuanya. Sehingga menjadi sebuah tradisi yang berkelanjutan bahwa satu individu akan mewarisi hal yang terkait dengan individu yang lain. Ibnu Khaldun menjelaskan bahwa taklid adalah sikap yang diambil oleh orang yang dikuasai untuk mengikuti orang yang menguasai atas dasar kerelaan. Penjelasan tersebut didasarkan bahwa menjadi sebuah kebiasaan ketika 
seseorang akan meyakini kesempurnaan orang yang menguasainya sehingga niscaya akan mengikutinya.

Adapun dalam disiplin ilmu jiwa, sikap taklid dapat dinyatakan sebagai sebuah proses kejiwaan yang terjadi pada manusia secara alami, dimana manusia sejak terlahir di muka bumi ini akan cenderung melihat fenomena-fenomena yang ada di lingkungannya untuk kemudian direspon balik, untuk kemudian menjadi terpengaruh atau pun mempengaruhi. Realitasnya seseorang akan terpengaruh dengan orang sekelilingnya, dari mulai pemikiran, perilaku, dan aktifitasnya. Potensi keterpengaruhan tersebut dapat menjadi entry point seseorang untuk dapat berdinamika dalam sebuah masyarakat.

\section{Ittiba', Tab'iyyah dan Keterkaitannya Dengan Taklid}

Pada dasarnya diksi ittiba' dan tab 'iyyah sebagai istilah yang digunakan untuk arti yang sama yaitu sikap seseorang mengikuti pendapat dan pikiran orang lain. Namun, keduanya ada sedikit perbedaan, bahwa ittiba' lebih dimaksudkan sebagai sikap mengikuti satu pendapat atau jalan pikiran orang lain, sedangkan tab iyyah dimaksudkan sebagai sikap mengikuti pendapat atau jalan pikiran orang lain secara berlebih di luar batasan yang telah ditetapkan (Ahmad : 57-60). Istilah ittiba' dalam perspektif syariat, adalah sebuah sikap mengikuti pendapat tertentu yang berlandaskan pada dalil yang benar, sehingga dapat dipahami bahwa dengan sikap ittiba' ini, seseorang dapat dikatakan sebagai orang yang mengikuti dalil syarak (Ahmad : 57-60).

Sementara itu, ketika dua istilah tersebut diatas dikaitkan dengan istilah taklid, maka dapat ditarik titik singgungnya bahwa ketiga istilah tersebut pada hakekatnya menunjuk pada arti yang sama, yaitu sebagai sikap mengikuti pendapat atau jalan pikiran orang lain. Hanya saja untuk istilah taklid dimaksudkan sebagai sikap mengikuti pendapat dan jalan pikiran orang lain dengan tanpa menggunakan pengetahuan dan penalaran terhadap dasar hukum pendapat tersebut, berkebalikan dengan ittiba' yang menggunakan pengetahuan dan penalaran, sedangkan tab'iyyah cenderung berlebih bahkan melewati batasan dalam mengikuti satu pendapat tertentu, baik dengan dasar pengetahuan dan penalaran terhadap dasar hukum pendapat tersebut atau tidak (Ahmad : 63-66).

\section{Rukun Taklid dan Jenis Taklid}

Yudisia, Vol. 9, No. 1, Jan-Jun 2018 
Dalam disiplin ilmu Ushul Fiqh, rukun taklid dapat dijelaskan terdiri dari tiga komponen pokok yakni: pertama, al-Muqallad Fih yang dimaksudkan sebagai sebuah pendapat atau topik tertentu yang dijadikan sebagai objek seseorang untuk melakukan taklid. Kemudian, pendapat atau topik yang dapat menjadi objek taklid dapat dijelaskan dengan ketentuan hukum sebagai berikut:

1. Taklid dalam akidah, dikandung maksud taklid terhadap hal-hal yang terkait erat dengan keyakinan terhadap hal-hal yang termasuk dalam pengetahuan dasar dan fundamental dalam agama Islam. Dalam hal ini ulama berbeda pendapat, mayoritas ulama berpendapat bahwa taklid dalam akidah termasuk dalam hal yang diharamkan, bahkan bagi seorang mukallaf diwajibkan untuk menggunakan nalar dan pemikiran yang mapan (Abdul Ali Muhammad, 2002, vol II: 433). Berbeda halnya dengan sebagian Ulama mazhab Syafi‘ $i$ dan al-Anbari yang memperbolehkan taklid dalam akidah, dan bahkan menggunakan nalar dan pemikiran yang mapan bukan merupakan sebuah kewajiban. Adapun mazhab Zahiri justru berpendapat wajib hukumnya bertaklid dalam akidah, dan bahkan diharamkan menggunakan penalaran.

2. Taklid dalam ushul al-din yang meliputi pemahaman terhadap sifat wajib, muhal dan jaiz bagi Allah Swt. Dalam hal ini, ulama berbeda pendapat, sebagian dari ulama menetapkan larangan taklid dalam ushul al-din, sementara mayoritas ulama justru memperbolehkan dengan pertimbangan bahwa ushul al-din dapat dimasukkan dalam kategori furu'.

3. Taklid dalam al-Furu' yang dimaksudkan dalam hal-hal yang terkait amaliah ibadah seseorang. Mayoritas ulama memperbolehkan taklid dalam hal tersebut. Dengan pertimbangan bahwa Allah Swt telah memerintah dalam surat an-Nahl: 43 bagi orang yang tidak mempunyai ilmu untuk bertanya kepada orang yang mempunyai ilmu. Tiada lain maksud dari perintah bertanya adalah menjalankan pendapat dari orang yang ditanya, sehingga dapat dijadikan dasar diperbolehkannya taklid dalam hal yang terkait dengan al-furu' Berbeda halnya dengan sebagian ulama tertentu yang tidak memperbolehkannya kecuali memang terkait dengan hukum yang valid argumentasinya.

Adapun komponen kedua adalah al-Muqallad yang dimaksudkan pada seseorang yang pendapat atau pola pikirnya 
dijadikan pegangan atau pedoman oleh orang lain. Sedangkan komponen ketiga adalah al-Muqallid yang dimaksudkan pada seseorang yang mengikuti pendapat orang lain.

Kemudian pembahasan terkait jenis taklid, dapat dijelaskan ke dalam dua jenis, yakni: pertama, taklid mahmud yang berarti taklid yang diperbolehkan, yaitu bentuk taklid yang dilakukan oleh orang yang tidak mampu untuk berijtihad dalam menentukan hukum. Oleh karena itu menjadi kewajiban baginya untuk mengikuti petunjuk seseorang yang memiliki kemampuan untuk berijtihad. Kedua, taklid madzmum/ muharram yang berarti taklid yang tidak diperbolehkan, yaitu taklid yang termasuk dalam salah satu taklid yang dapat menyebabkan berpaling dari Al-Qur'an; atau taklid kepada seseorang yang belum diketahui kualitas keilmuannya; dan atau taklid yang dilakukan setelah munculnya dalil yang bertentangan dengan pendapat orang yang diikuti (AzZuhaili, 1986, II: 1129).

\section{E. Esensi Nilai-nilai Kebangsaan Yang Bersumber Pada Empat Pilar Kebangsaan}

Dalam rangka menjaga keutuhan NKRI, dengan sebuah upaya sungguh-sungguh untuk menumbuhkan rasa cinta tanah air, bangsa ini telah menyepakati empat pilar, sebagai penyangga keutuhan persatuan dan kesatuan bangsa. Keempat pilar tersebut adalah Pancasila, UUD 1945, Bhineka Tunggal Ika dan NKRI. Keempat pilar tersebut sarat dengan makna dan filosofi yang mendalam, sebab nilai esensial yang muncul dari keempat pilar tersebut menjadi identitas nasional dan menjadi cita-cita bersama segenap komponen bangsa Indonesia yang akan terus diperjuangkan dan dipertahankan sampai titik darah penghabisan.

Nilai esensial kebangsaan yang muncul dari keempat pilar kebangsaan tersebut dapat dijelaskan dengan rincian sebagai berikut:

1. Nilai-nilai kebangsaan yang muncul dari tiap sila dari kelima sila dalam Pancasila adalah sebagai berikut:

a. Nilai religiusitas, dimaksudkan sebagai nilai yang menjadikan manusia Indonesia memiliki nilai spiritual yang tinggi yang berlandaskan kepada agama dan keyakinan yang dipeluknya dan memiliki toleransi terhadap pihak lain. Nilai tersebut menghendaki bahwa manusia Indonesia beragama dan berkeyakinan secara berkebudayaan.

Yudisia, Vol. 9, No. 1, Jan-Jun 2018 
b. Nilai kekeluargaan, dimaksudkan sebagai nilai yang menjadikan manusia Indonesia memiliki rasa kebersamaan, memiliki rasa yang sama sebagai bagian dari komponen bangsa, tanpa membedakan asal usul, agama-keyakinan, latar belakang sosial dan politik seseorang untuk mewujudkan cita-cita bersama sebagaimana disepakati dan tercantum dalam pembukaan UUD 1945.

c. Nilai keselarasan, dimaksudkan sebagai nilai yang menjadikan manusia Indonesia memiliki kemampuan dan keterampilan menghargai kekayaan budaya dan kearifan lokal yang dimiliki bangsa ini, sebagai perwujudan dari nilai-nilai kemajemukan Indonesia.

d. Nilai kerakyatan, dimaksudkan sebagai nilai yang menjadikan manusia Indonesia terlebih bagi pemangku kepentingan untuk dapat memiliki sifat dan komitmen keberpihakan kepada kepentingan rakyat banyak dalam merencanakan, merumuskan dan menjalankan kebijakan publik, sebagai perwujudan dari prinsip kedaulatan rakyat dan bangsa yang berdaulat.

e. Nilai keadilan, dimaksudkan sebagai nilai yang menjadikan manusia Indonesia untuk dapat memiliki kemampuan dan kemauan yang kuat untuk menegakkan keadilan berdasarkan peri keadilan dan peri kemanusiaan demi terwujudnya keadilan bagi seluruh rakyat Indonesia.

2. Nilai-nilai kebangsaan yang muncul dari Undang-undang Dasar 1945 adalah sebagai berikut:

a. Nilai demokrasi, dikandung maksud sebagai nilai yang dapat memastikan bahwa kedaulatan penuh di Indonesia berada di tangan rakyat, sehingga setiap warga negara dapat dipastikan berhak mendapatkan kebebasan untuk berserikat dan berpendapat secara bertanggung jawab.

b. Nilai kesamaan derajat, dimaksudkan bahwa dengan nilai kesedarajatan tersebut, setiap warga negara memiliki kedudukan yang sama dalam hak dan kewajiban yang dimiliki di hadapan hukum.

c. Nilai ketaatan hukum, dimaksudkan bahwa dengan nilai ketaatan tersebut dapat dipastikan bahwa setiap warga negara tanpa memandang latar belakang yang dimiliki diwajibkan untuk tunduk dan patuh pada undang-undang atau peraturan yang berlaku. 
3. Nilai-nilai kebangsaan yang bersumber dari NKRI, antara lain :

a. Nilai kesatuan wilayah, dimaksudkan sebagai nilai yang mampu memastikan bahwa kendati Indonesia sebagai negara kepulauan yang terdiri dari ribuan pulau yang tersebar di seluruh pelosok negeri dan terpisah oleh perairan, namun tetap menjadi satu, dalam satu kesatuan wilayah Indonesia.

b. Nilai persatuan bangsa, dimaksudkan sebagai nilai yang memastikan bahwa seluruh komponen bangsa bersatu dalam satu kebangsaan yang sangat majemuk terdiri dari ragam agama, suku, budaya, politik dan sebagainya.

c. Nilai kemandirian dimaksudkan sebagai nilai untuk memastikan bahwa bangsa dan negara ini dibangun atas dasar prinsip kemandirian dengan mengoptimalkan kemampuan sumber daya manusia, alam dan budaya yang dimiliki Indonesia untuk kemudian diprioritaskan seluasluasnya bagi kesejahteraan dan kejayaan bangsa Indonesia (national interests).

4. Nilai-nilai kebangsaan yang bersumber dari Bhineka Tunggal Ika antara lain:

a. Nilai toleransi, nilai yang dimaksudkan untuk dapat memastikan komponen bangsa ini mampu memahami dan menerima keberadaan orang lain yang berseberangan dalam segenap aspek kehidupan untuk kemudian dapat hidup berdampingan secara damai.

b. Nilai keadilan, nilai yang dimaksudkan untuk dapat memastikan bahwa segenap warga negara bisa seimbang antara hak dan kewajiban.

c. Nilai gotong royong, nilai yang dimaksudkan bahwa segenap komponen bangsa mampu untuk bekerjasama dalam urusan-urusan yang terkait dengan kepentingan bersama, kemasyarakatan dan negara.

\section{F. Metode Penelitian}

Kajian ini bersifat deskriptif-kualitatif, dengan pertimbangan adanya kualitas data yang terkait dengan variabel penelitian berupa pola taklid beragama umat Islam Indonesia dan pengaruhnya terhadap nilai-nilai kebangsaan, yang tentunya membutuhkan interpretasi yang mendalam terhadap makna yang terkandung, berikut konteks yang melingkupinya, dan tentunya pula, membutuhkan upaya penggambaran secara sistematis dan akurat 
terhadap fakta dan karakteristik dari data-data tersebut (Azwar, 2011: 7).

Kemudian, kajian ini dilakukan dengan menggunakan dua pendekatan: pertama, library research dengan pertimbangan bahwa pelaksanaan penelitian bertumpu pada penelaahan kritis dan mendalam terhadap bahan-bahan pustaka yang relevan dengan variabel dalam kajian ini. Kedua, field research dengan pertimbangan bahwa pelaksanaan penelitian bertumpu pada interaksi peneliti dengan realitas di lapangan yang menjadi subyek penelitian (Sarwono, 2006: 18).

Kajian ini dilakukan dengan mengacu pada sumber data yang relevan, yang dapat dirincikan ke dalam dua bagian: pertama, terkait library research, peneliti menggunakan sumber data dari literatur Ushul Fiqh yang tersedia di dalam empat madzhab, antara lain: 1) Dalam mazhab Hanafi menggunakan kitab Usul al Sarkhasi, bazl al-nazar, al-Taqrir wa al-Tahbir, Taisir al-Tahrir, Kasyf al-Asrar, Usul al-Syasi, dan Fawatih al-Rahamut. 2) Dalam mazhab Maliki menggunakan kitab Syarh tanqih al-Fusul, alMuwafaqat, dan Taqrib al-Wusul ila 'ilm al-Usul. 3) Dalam mazhab Syafi'i menggunakan kitab al-Bahr al-Muhit, al-Tahsil mi al-Mahsul, Syarh al-Luma', al-Mahsul fi 'ilm Usul al-Fiqh, Nihayat al-Wusul, al-Mustasfa, Nihayat al-Sul dan Jam'alJawami : 4) Dalam mazhab Hanbali menggunakan kitab Ithaf zawi al-Basair, al-Tamhid fi Usul al-Fiqh, al-'Uddah, dan Syarh alKawkab al-Munir. Adapun yang terkait field research, peneliti menggunakan sumber data yang diperoleh dari informan yang peneliti batasi pada warga simpatisan ormas Islam di wilayah administratif kabupaten Kudus Provinsi Jawa Tengah.

Dari paparan sumber data tersebut di atas, terkait dengan pendekatan library research peneliti melakukan penggalian data dengan menggunakan teknik dokumentasi yang dimaksudkan untuk mencari data yang terkait dengan variabel penelitan yang bersumber dari literatur yang terkait (Arikunto, 2003: 274-275). Adapun yang terkait dengan field research, peneliti menggunakan teknik wawancara sebagai upaya peneliti untuk menggali data yang kaya dan multidimensi mengenai suatu hal dari para partisipan.

Di samping itu, peneliti juga menggunakan kuesioner dengan pertimbangan untuk mendapatkan informasi lebih banyak dari responden, mengingat tekhnik wawancara sangat terbatas tempat dan waktu. Sebagai teknik tambahan, peneliti memanfaatkan teknik 
focus group discussion (FGD) dengan pertimbangan untuk menggali lebih dalam informasi dari responden terkait konsep taklid, sebagai antisipasi adanya informasi yang terlewatkan dalam wawancara.

Terkait analisis terhadap data yang telah peneliti dapatkan, ada beberapa langkah yang peneliti lakukan, yaitu: 1) Menemukan kata-kata penting, simbol-simbol, argumen-argumen yang relevan dengan tujuan penelitian; 2) Mengintepretasikan temuan-temuan tersebut untuk kemudian dibuat kategorisasi; 3) Menyajikan temuan dalam sebuah narasi yang utuh; 4) Menentukan hipotesis kerja mengenai hubungan antar kategori yang telah dibuat; dan terakhir 5) Menguji keabsahan asumsi-asumsi atau klasifikasi yang telah dikonstruksi berdasarkan data yang terkumpul. (Afrizal, 2013:185-187).

\section{G. Konsep Taklid, Validitas dan Urgensinya dalam Perspektif Ushul Fiqh Empat Mazhab}

Berdasarkan pada varian definisi taklid dalam perspektif Ushul Fiqh empat mazhab sebagaimana telah dipaparkan di atas, pada dasarnya mengandung konsep yang sama. Adapun perbedaan yang ada pada masing-masing definisi, tidak lebih secara redaksional semata. Prinsipnya, secara konseptual, pemahaman tentang taklid mengacu pada tiga aspek, yaitu: pertama, adanya reaksi dari pihak yang mengikuti (muqallid), baik berupa tindakan atau pun sebuah sikap terhadap pendapat yang dikemukakan oleh orang yang diikuti (muqallad). Aspek tersebut tampak pada diksi yang dipakai dalam masing-masing definisi secara istilah antara lain: إنذ dan إنباع , إلتزام , عمل , إبول. Masing-masing diksi tersebut dapat memberikan pemahaman bahwa taklid adalah bentuk reaksi seorang muqallid untuk mengikatkan dirinya dan membatasi dirinya dengan pendapat seorang muqallad untuk dijadikan acuan dalam setiap aktivitas keberagamaannya.

Di samping itu, penjabaran dari arti pengikatan dan pembatasan tersebut dapat juga ditelusuri dari sudut pandang arti taklid secara bahasa, antara lain: ihatah (إحاطة) mempunyai arti mencakup, meliputi, membungkus, sehingga bisa dikatakan bahwa orang yang taklid sama halnya mengikuti orang lain dengan sebuah rantai yang melingkar di leher; ghita' (غطاء) berarti tutup, sehingga orang yang taklid sama halnya menutupi pikiran dan penalarannya terhadap sesuatu hal yang diikuti; ilzam (إلزام) yang berarti

Yudisia, Vol. 9, No. 1, Jan-Jun 2018 
menetapkan, sehingga orang yang taklid menetapkan dirinya untuk mengikuti pendapat tertentu; tatabbu ' تتبع) yang berarti mengikuti, sehingga orang yang taklid sama halnya mengambil suatu pendapat untuk selalu diikuti di setiap hari; al-Sabq (السبق) yang berarti dahulu, sehingga orang yang taklid telah didahului oleh orang yang diikuti dalam hal berfikir tentang sesuatu hal; al-Muhakah wa alIttiba ' min ghair tafkir (المحاكاة والإتباع من غير تفكير) yang berarti menceritakan dan mengikuti suatu hal tanpa memikirkannya, sehingga seseorang yang taklid seolah menceritakan hal-hal yang terkait dengan orang yang diikuti, kemudian mengikutinya tanpa menggunakan penalaran yang memadai.

Aspek kedua, adanya pendapat orang lain yang merupakan hasil dari ijtihad yang dilakukan, dan tidak termasuk dalam kategori sumber hukum Islam yang dibakukan. Ketentuan diksi 'pendapat' tersebut diatas tidak semata-mata dalam segi ucapan saja, bahkan mencakup tindakan dan sikap seorang muqallad. Ketiga, tanpa adanya argumentasi yang dapat dipertanggung jawabkan, dikandung maksud bahwa taklid merupakan sebuah tindakan mengikuti pendapat orang lain, tanpa dilandasi atau pun didorong oleh pertimbangan-pertimbangan yang dibenarkan oleh syariat Islam.

Selanjutnya, pembahasan tentang validitas konsep taklid dalam perspektif Ushul Fiqh empat mazhab, pada dasarnya dapat disepakati pembenarannya sebagai salah satu konsep yang memberikan jalan keluar bagi seorang yang awam hukum Islam untuk mengikuti pendapat orang lain yang dipandang mempunyai kapabilitas dalam penetapan hukum sarak. Beberapa pernyataan dari keempat mazhab terkait hal tersebut dapat dipaparkan dengan perincian sebagai berikut:

\section{Mazhab Hanafi}

Dalam kitab al Taqrir wa al Tahbir (1999, vol III: 438) disebutkan redaksi sebagai berikut:

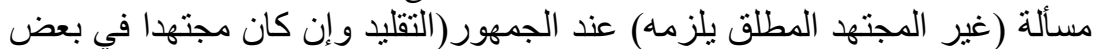

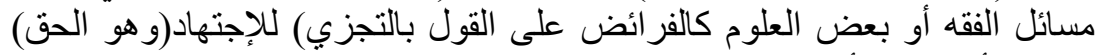

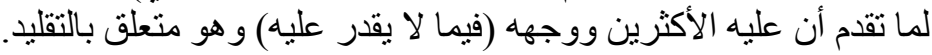

Mayoritas ulama menjelaskan bahwa seseorang yang tidak termasuk sebagai mujtahid mutlak, atau pun termasuk mujtahid namun secara parsial, wajib baginya untuk bertaklid dalam hal hal yang di luar kemampuannya. Pendapat itu lah yang sebenarnya. 


\section{Mazhab Maliki}

Demikian juga dalam kitab Taqrib al Wusul ila ilm al Usul (2002: 445) dengan menggunakan redaksi sebagai berikut:

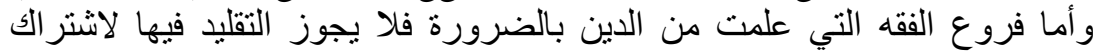

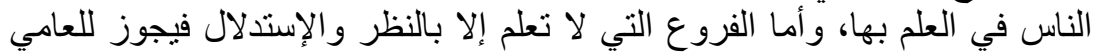

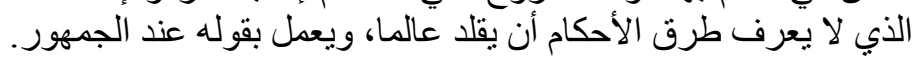
Adapun hal-hal furu' yang termasuk dalam kategori sebagai pengetahuan baku di dalam agama, maka tidak diperkenankan melakukan taklid, sedangkan furu' yang mensyaratkan adanya penalaran, maka bagi orang awam yang tidak mengetahui metode penetapan hukum diperbolehkan mengikuti dan menjalankan pendapat ulama, sebagaimana pendapat mayoritas ulama.

3. Mazhab Syafi'i

Dalam kitab al Mankhul min Ta'liqat al Usul (tt: 472) dipaparkan sebagai berikut:

$$
\text { وقال القاضي لا معنى للتقليد ويجب على العامي قبول قول المفتي. }
$$

Wajib bagi orang awam menerima pendapat seorang yang berfatwa.

4. Mazhab Hanbali

Dalam kitab Syarh Mukhtasar al Rawdah (1998, vol III: 652)

$$
\text { قوله ويجوز التقليد في الفروع إجماعا أي بالإجماع }
$$

Diperbolehkan untuk bertaklid terhadap hal-hal yang termasuk dalam kategori furu', sesuai dengan ijmak ulama.

Berdasarkan beberapa pendapat tersebut di atas, pada prinsipnya keempat mazhab mempunyai pendapat yang sama, bahwa tindakan seseorang untuk taklid kepada pendapat orang lain dalam perilaku keagamaannya merupakan sesuatu yang dibenarkan dalam Islam. Hanya saja, ada sedikit penjelasan dalam mazhab Maliki, bahwa taklid yang dibenarkan adalah hanya pada hal-hal yang tidak termasuk dalam urusan yang sifatnya baku dan dasar dalam ajaran Islam. Sedangkan terhadap hal-hal yang bersifat baku tidak diperkenankan taklid kepada pendapat orang lain, bahkan diwajibkan untuk dapat menalar.

Pembahasan selanjutnya, terkait urgensi konsep taklid dalam penerapan hukum Islam, dapat dijelaskan sebagai berikut:

1. Konsep ijtihad dalam disiplin Ushul Fiqh tidak mudah untuk dilaksanakan, terutama bagi kalangan awam, mengingat persyaratan yang harus dipenuhi sangat ketat. Oleh karena itu, konsep taklid tidak lain adalah sebagai jalan keluar bagi orang

Yudisia, Vol. 9, No. 1, Jan-Jun 2018 
awam yang tidak memenuhi kualifikasi untuk melakukan ijtihad.

2. Keberadaan orang yang memenuhi kualifikasi ijtihad sangat lah minim, oleh karena itu konsep taklid menjadi salah satu konsep yang sangat dibutuhkan dalam upaya menerapkan hukum Islam.

3. Konsep taklid menjadi sangat penting bagi orang awam ketika menghadapi suatu masalah yang harus direspon dengan secepatnya, untuk menghindari terjadinya kekosongan hukum.

4. Praktik taklid sangat terkait erat dengan terwujudnya hidup yang produktif. Dikarenakan ketika orang mukallaf dibebankan untuk mampu menguasai keterampilan berijtihad, tentunya banyak sekali aspek kehidupan yang terabaikan, bahkan akan sangat berpengaruh terhadap terwujudnya kualitas hidup yang ideal.

5. Larangan taklid akan dapat menimbulkan resiko bagi manusia, padahal syariat Islam diturunkan untuk menghilangkan resiko dalam kehidupan umat manusia.

\section{H. Implementasi Taklid dalam Beragama dan Pengaruhnya Terhadap Nilai-nilai Kebangsaan NKRI}

Pada prinsipnya implementasi sikap taklid dalam menjalankan ajaran agama berpengaruh cukup signifikan terhadap nilai-nilai kebangsaan yang akan senantiasa dipertahankan keberlangsungannya sebagai identitas nasional bangsa Indonesia. Keterpengaruhan itu terjadi sebagai konsekuensi logis yang muncul dari sikap taklid, yaitu; pertama, melemahnya nalar kritis, terlebih dalam persoalan kualitas informasi terkait ajaran agama. Kedua, mandulnya daya kreatifitas terkait dengan strategi penerapan ajaran agama.

Pembahasan terkait nalar yang melemah secara jelas akan terlihat pada sikap yang diambil seorang muqallid dalam menjalankan ajaran agama, berdasarkan informasi dari seorang muqallad, dimana seorang muqallid akan begitu mudahnya menerima informasi tersebut bahkan acap kali memunculkan reaksi dengan menganggapnya sebagai sebuah kebenaran yang final, seringkali upaya filterisasi (tafshil) atau pun klarifikasi (tahqiq) dianggap belum cukup memadai. Bahkan reaksi tersebut tidak menutup kemungkinan akan menghantarkan seorang muqallid dengan begitu mudahnya sampai pada sikap fanatik (ta'ashshub).

Adapun konsekuensi kedua yaitu daya kreatifitas yang mandul, sebagai akibat lanjutan dari lemahnya daya nalar. Daya 
kreatifitas ini seharusnya menjadi modal besar umat Islam untuk mampu menyesuaikan ajaran Islam sesuai dengan lingkungan dalam rangka meneguhkan misi Islam sebagai agama yang bertujuan menebarkan kasih sayang ke seluruh makhluq ciptaan Allah di seluruh penjuru alam semesta. Sehingga ketika daya kretifitas tersebut mengalami mati suri, tentunya akan ada ketimpangan dalam tata kehidupan makhluq di muka bumi ini. Di samping itu, hadirnya Islam di bumi Nusantara ini dan keberadaan negara kesatuan republik Indonesia sudah semestinya dapat dipastikan ada hubungan saling menguntungkan antar keduanya, sebab pada dasarnya nilai-nilai kebangsaan yang dianut di negeri ini, hampir dapat dipastikan selaras dengan nilai-nilai universal yang diperjuangkan oleh Rasulullah Saw untuk turut serta mewarnai peradaban manusia di muka bumi ini, terlebih di bumi pertiwi.

Oleh karena itu ketika umat Islam di negeri ini dalam berbangsa dan bernegara lebih memilih sikap taklid dalam menjalankan ajaran agamanya, terlebih lagi taklid buta, tentunya misi untuk menebarkan nilai kasih sayang akan sedikit banyak mengalami hambatan. Andai sekalipun tetap mempertahankan sikap bertaklid dalam menjalankan ajaran agama, paling tidak dapat diupayakan untuk mengetahui dasar argumentasinya sebagaimana uraian dalam mazhab Maliki di atas, dalam istilah Ushul Fiqh disebut dengan ittiba :

\section{Simpulan}

Berdasarkan hasil dari pembahasan sebagaimana diuraikan di atas, dapat lah disimpulkan beberapa hal sebagai berikut:

1. Sikap taklid menurut empat mazhab Ushul Fiqh pada prinsipnya adalah sebuah sikap yang diambil oleh seorang muqallid untuk mengikatkan dirinya atas pendapat seorang muqallad dalam kaitannya terhadap seluruh aktifitas keagamaannya.

2. Dalam disiplin Ushul Fiqh empat mazhab, dinyatakan bahwa sikap taklid termasuk dalam kategori sikap yang dapat diterima dan dapat ditemukan pembenarannya terkait dengan praktik keberagamaan seseorang, di samping itu, sikap taklid dapat dijadikan solusi, mengingat prasyarat berijtihad tidak serta merta dapat dipenuhi oleh khalayak umum dengan mudah.

Yudisia, Vol. 9, No. 1, Jan-Jun 2018 
Alfa Syahriar \& Ahmad Fauzan Mubarok

3. Sikap taklid dalam beragama hampir dapat dipastikan akan berpengaruh terhadap eksistensi keberlangsungan nilai-nilai kebangsaan NKRI, sebagai konsekuensi dari daya nalar yang melemah dan daya kreatifitas yang mandul. 


\section{DAFTAR PUSTAKA}

Abu Ya'la. 1993. Al- 'Uddah. Riadh

Abdul Aziz. 1997. Kasyf al-Asrar 'an Usul Fakhr al-Islam alBazdawi. Beirut: Dar Al-Kutub Al-Ilmiyyah.

Abu Zar'ah. 2004. al-Ghait al-Hami' Syarh Jam' al-Jawami'. Beirut: Dar al-Kutub al-Ilmiyyah.

Afrizal. MA. Prof. Dr. 2014. Metode penelitian kualitatif. Jakarta: Rajawali Press.

Ari Kunto, Suharsini. Prof. Dr. 2013. Prosedur Penelitian; Suatu Pendekatan Praktik. Jakarta: Rineka Cipta.

Azwar, Saifuddin. MA, Dr. 2011. Metode Penelitian. Yogyakarta: Pustaka pelajar

Al-Subuki. 1999. Raf' al-Hajib an Mukhtashar Ibn al-Hajib. Beirut: Alam al-Kutub.

Al-Najjar, Ibnu. 1993. Syarh Kaukab al-Munir. Riadh: Maktabah Obeikan.

Al-Syairazi. 1995. Al-Luma'. Damaskus: Dar Ibnu Katsir.

Al-Juwaini. 1996. Al-Waraqat. Riadh: Dar al-Shomi'i.

Al-Anshori. 1418. Fawatih al-Rahamut bi Syarh Muslam alTsubut. Beirut: Dar Ihya at-Turats al-Arabi.

Al-Mardawi. t.t. At-Tahbir Syarh At-Tahrir . Riadh: Maktabah arRusyd.

Al-Hindi. t.t. Nihayat al-Wusul fi dirayat al-Usul. Makkah: Maktabah At-Tijariyyah.

Al-Qarrafi. 1995. Nafais al-Usul fi syarh al-Mahsul. Riadh: Maktabah Nizar.

Al-Amidi. 2003. al-Ihkam fi Usul al-Ahkam. Riadh: Dar alShami'i, cet I.

Al-Zuhaili, Wahbah. Dr. 1986. Usul Fiqh al-Islamiy . Beirut: Dar El-Fikr.

Ibn Fahd, Ahmad. 1433. Mafhum al-Taqlid. Tesis. Univ. Muhammad Ibn Saud.

Ibnu Ash-Sholah. 2002. Adab al-Mufti wa al-Mustafti. Madinah: Maktabah Ulum wal Hikam.

Ibnu As-Subuki. 2003. Jam ' al-Jawami` . Beirut: Dar Al-Kutub AlIlmiyyah.

Ibn Abdussalam. 1994. Qawaid al-Ahkam fi Masalih al-Anam. Kairo: Maktabah al-Kulliyyat al-Azhariyyah.

Yudisia, Vol. 9, No. 1, Jan-Jun 2018 
Isfirayini. 1992. Al-Bahr al-Muhit. Kuwait: Kementrian Wakaf dan Urusan Agama.

Ibn Juzzai. 2002. Taqrib al-Wusul Ila ilm al-Usul.

Nazir, Moh. Ph.D. 2014. Metode Penelitian. Bogor: Penerbit Ghalia Indonesia.

Sugiyono. Prof. Dr. 2012. Metode penelitian Kombinasi. Bandung: Alfabeta.

Sarwono, Jonathan. 2006. Metode Penelitian Kuantitatif dan kualitatif. Yogyakarta: Penerbit Graha Ilmu.

Sarosa, Samiaji. S.E., M.Sc., Ph.D. 2012. Penelitian Kualitatif Dasar-dasar. Jakarta: PT Indeks.

Umar, Husein. S.E., MBA., M.M., Dr. 2011. Metode Penelitian untuk Skripsi dan Tesis Bisnis. Jakarta: Rajawali Pers. 